\title{
Folate Receptor Family Positive
}

National Cancer Institute

\section{Source}

National Cancer Institute. Folate Receptor Family Positive. NCI Thesaurus. Code C153242.

An indication that expression of a member of the folate receptor family has been detected in a sample. 